\title{
'SINK OR SWIM?': LEARNING FROM STORIES OF BECOMING ACADEMICS WITHIN A TRANSFORMING UNIVERSITY TERRAIN
}

\author{
K. Pithouse-Morgan* \\ e-mail: pithousemorgan@ukzn.ac.za
}

\section{Naicker*}

e-mail: naickeri1@ukzn.ac.za

\author{
D. Pillay* \\ e-mail: pillaygv@ukzn.ac.za
}

\author{
L. Masinga* \\ e-mail: masingal@ukzn.ac.za \\ T. Hlao* \\ e-mail: hlao@ukzn.ac.za \\ * School of Education \\ University of KwaZulu-Natal \\ Durban, South Africa
}

\section{ABSTRACT}

The meanings connected with becoming or being an academic are constantly shifting, on account of diverse forces that act on universities. In this article, we portray our learning as a research team of four academics (including one early-career academic) and a doctoral student who took a narrative inquiry approach to listening and responding to our early-career colleagues' stories of becoming and being academics within a transforming university landscape. Imaginative engagement with these stories through the evocative and reflexive medium of poetry awakened possibilities for navigating the uncertain terrain of academia. The article draws attention to collegial relationships as critical to the growth of self-belief and self-resourcefulness in becoming and being academics. It demonstrates how, through collective participation, novice and experienced academics can become valuable sources of learning and support for each other.

Keywords: collegiality, early-career academics, narrative inquiry, poetry, reflexivity, university transformation

\section{A POETIC PRELUDE \\ Overwhelmed, scattered Vulnerable and exposed Have to find your way To go forward together The self becomes the resource}

\section{INTRODUCTION}

The watershed political transition in South Africa in 1994 heralded significant changes in higher education guided by a vision of a transformed, democratic, non-racial and non-sexist system of higher education (Badat 2010). To realise this vision it is imperative to develop the 
next generation of academics (National Planning Commission 2012). The meanings associated with becoming or being an academic and what constitutes academic work are contested and constantly changing, owing to the different forces (most notably the recent corporatisation discourse) that act on universities (Debowski 2012). Becoming an academic is not smooth, straightforward, linear or automatic. It can involve conflict and instances of marginalisation and exclusion (Archer 2008). In this article we offer an account of our learning as a research team of four academics (including one early-career academic) and a doctoral student who took a narrative inquiry approach to make meaning from our earlycareer colleagues' stories of becoming and being academics within a transforming university landscape. We use the medium of poetry to represent how we were collectively able to rethink our experiences and understandings of becoming and being academics.

We begin by discussing higher education transformation in South Africa within a context of corporate managerialist reforms and the impact of this on early-career academics. Next we highlight significant features of the poetic narrative inquiry methodological approach that informs this article. We then retrace our research process as we deliberate on how we have learned through: a) using poetry with early-career academics to generate field texts (research data sources); b) composing a research poem to convey what we saw as the 'essence of ... experience ... being represented' by our early-career colleagues (Furman, Lietz and Langer 2006, 27); and c) creating an interpretive poem that reflected our understanding of and response to our colleagues' stories of experience, thus allowing us to 'become autobiographically conscious of our own reactions to our work' and also to awaken 'possibilities for reliving, for new directions and new ways of doing things' (Clandinin and Connelly 2000, 46,189). To end we consider what we have learned by using poetic narrative inquiry to listen and respond to early-career academics' stories of experience. We draw attention to collegial relationships as critical to the growth of self-belief and selfresourcefulness in becoming and being academics.

\section{PUTTING OUR RESEARCH INTO CONTEXT}

In respect of management and governance, higher education transformation in South Africa appears to have largely mirrored corporate managerial reforms that have been seen in higher education internationally. To illustrate, Clare and Sivil $(2014,62)$ observe that the transformation agenda in the South African higher education sector has seen 'the application of [an] economic ideology to the education sector'. Likewise, Habib (2010) argues that managerial practices and accountability mechanisms from the corporate sector have 
unthinkingly been imported into South African universities. This has resulted in a reculturing and reorganisation of universities and their various departments into business entities, where academic activities are managed through strategic control with emphasis placed on outputs that can be quantified and compared (Reid 2009).

Habib (2010) explains the effects of these managerial practices on universities by pointing out that: academic departments have had their budgets slashed; the workloads of academics have increased significantly; there is a greater push for third-stream income; and quantitative indicators of performance have begun to proliferate. In essence what is happening is that the university as an authentic source of knowledge production is being turned into a knowledge factory, which Teferra (2014, paragraph 3) refers to as a shift from an open space of 'scholar-ship' to a marketplace of 'business-ship'. This then is the organisational terrain in which many early-career academics (in South Africa and internationally) find themselves.

Academic work is characterised by multiple tensions through which new academics must navigate their way (Adcroft and Taylor 2013). One such tension is that of the competing demands placed on early-career academics' time and resources by research, teaching, community engagement and administration (Price, Coffey and Nethery 2014). While teaching might be important to early-career academics, on a practical level - with a heavy teaching load - they often find it difficult to allocate time for research and writing in order to develop their scholarly profile (Fitzmaurice 2013). In the prevailing performative climate, performance measures create hierarchies that can relegate early-career academics to the lower levels because they might not have managed to build the portfolio of publications, research supervision and successful grant bids that universities require (Eley, Wellington, Pitts and Biggs 2012). The pressure to publish and increased demands for accountability can lead to teaching and research being viewed as separate and conflicting entities rather than as activities that are intertwined. For many new academics teaching takes up a great deal of time, but it is their research profiles that are commonly most important for career progression (Eley et al. 2012).

A second tension, identified by Adcroft and Taylor (2013), is between visible and invisible rules that operate in academia. For example, Sternberg (2014) emphasises that academic performance should be judged on a combination of scholarship, teaching and service (to institution and profession). What is problematic is that academics might also be evaluated on two criteria that are less likely to be made explicit: their reputation and their perceived fit with the institution (Sternberg 2014). As Sternberg highlights, these criteria can be sources of confusion in the university terrain and can be unsettling for early-career 
academics.

It was against this backdrop of a reculturing and reorganisation of universities internationally and nationally towards a performative ethos, together with the tension of the national imperative to develop the next generation of academics, that we sought to learn from our early-career colleagues' stories of experience. Our thinking about the inquiry that we present in this article began when we were approached by colleagues from our institution's University Teaching and Learning Office (UTLO) who asked if we would be interested in doing qualitative research to elicit teaching-related experiences and views of early-career academics who had been working as academics for no more than five years as of 2014. We agreed on condition that we could take a creative and participatory approach to the research. This was because of our own research interests and our shared view that creative and participatory approaches are beneficial in understanding the texture, depth and complexity of lived human experience (see, for example, Masinga 2012; Pithouse-Morgan et al. 2014).

We are based in a School of Education at a research-intensive South African university, where we teach and research in diverse academic specialisations: Teacher Development Studies (Kathleen, Daisy and Teboho), Educational Leadership and Management (Inbanathan), and Gender and Education (Lungile). We have been working together in varied ways for a number of years. Daisy and Kathleen teach together in the specialisation of Teacher Development Studies. They are Teboho's doctoral research supervisors and Teboho works with them as a graduate assistant on several research projects. Daisy, Kathleen and Inbanathan work together on a range of funded research projects. Kathleen was Lungile's Master's and doctoral research supervisor. Kathleen, Daisy, Inbanathan and Lungile are all part of an inter-university, transdisciplinary learning community of research supervisors that meets regularly (see Pithouse-Morgan et al. 2015; Van Laren et al. 2014).

Our interconnectedness means that our work is underpinned by working relationships that have developed over the years, and that we begin any new research endeavour with a sense of mutual trust and understanding which allows us to try out new ideas and research practices without fear of judgement or ridicule from each other. We are aware that our relationships as researchers are fundamental to the processes and outcomes of our research (Naicker, Morojele, Pithouse-Morgan, Pillay and Chikoko 2014).

\section{NARRATIVE INQUIRY, RESEARCH REFLEXIVITY AND POETRY}

Narrative inquiry is a qualitative research methodology that is used to make sense of human lives as told in stories of experience (Clandinin and Connelly 2000). As Clandinin (2013) 
explains, narrative inquiry embraces a reflexive dimension that is often absent in accounts of educational research (Walford 1991). The methodological and ethical purpose of research reflexivity - or putting ourselves as researchers in the picture - is to become 'more mindful of how ourselves, positionings, understandings, and beliefs as researchers interact with research processes and influence the educational representations and explanations we produce' (Pithouse-Morgan, Mitchell and Pillay 2014, 1). Consequently, as narrative inquirers we need to pay close attention to our experience as researchers and to make ourselves visible in the research texts that we create (Connelly and Clandinin 1994). It is also important for us to bear in mind that who we are will have an impact on the research stories that we tell, and that the way in which we tell these stories is likely to have a reciprocal effect on us and our research participants (Conle 1999).

Research texts are commonly constructed using prosaic written language (Caulley 2008; Sand-Jensen 2007); prosaic language can be understood as language that is written in the form of prose (i.e. not written in poetic form). It can also be understood as language that is used in ways that are straightforward, unemotional, unimaginative, and even dull (American Heritage ${ }^{\circledR}$ Dictionary of the English Language 2011). The origins of the words prosaic and prose can be found in the Latin word provorsus, which means '(moving) straight ahead' (Online Etymology Dictionary (2001-2014), 'prose'). In contrast, the word reflexive has its origins in the Latin word reflexivus, which implies 'capable of bending or turning back' (Online Etymology Dictionary (2001-2014), 'reflexive'). Prosaic language therefore seems suitable for constructing straightforward accounts of educational research that map out a linear progression to a definitive endpoint. However, narrative inquiry, which is 'simultaneously focused in four directions: inward and outward, backward and forward' (Clandinin and Connelly 1994, 417), calls for forms of written language that are more evocative, imaginative and fluid and 'whose limits differ from those imposed by propositional discourse and number' (Eisner 1997, 5).

Poetry is increasingly being recognised by qualitative researchers (including narrative inquirers) as a medium for evocative and reflexive writing (see, for example, Van Manen 1990; Richardson 2003; Leggo 2008; Clandinin 2013). As Chisanga, Rawlinson, Madi and Sotshangane (2014, 32) elucidate, poetry can: '[encapsulate] our life experiences by describing the feelings of the writers of the piece'. In this article we seek to contribute to scholarly conversations about intersections between poetry, narrative inquiry and research reflexivity by exploring our use of poetry throughout a narrative inquiry process. 


\section{USING POETRY WITH EARLY-CAREER ACADEMICS TO GENERATE FIELD TEXTS}

Using a database of contact information generated by the university's human resources division, we sent email invitations via the UTLO to 198 early-career academics across all four colleges of the university to participate in a half-day research workshop. Thirteen early-career academics from three of the university's four colleges chose to attend. In the light of the National Development Plan imperative to increase the numbers of PhD-qualified black and women academics (National Planning Commission 2012), it is significant that the group consisted of seven black women, four black men and one white man. In addition, 12 of the 13 did not yet hold a $\mathrm{PhD}$ qualification.

Some of these academics knew each other and us, while others had never met each other or us before. We began the workshop with introductions and a brief explanation by the research team of our research interests and intentions. Having heard more about our plans, one of the attendees chose not to join in, leaving us with 12 participants. In keeping with the ethics requirements of our university, we asked the participants to sign letters of informed consent.

Next we moved into a participatory ‘tweet poem' activity, based on a collective poetic research practice that we developed with other colleagues to study our own experiences as postgraduate research supervisors (see Pithouse-Morgan et al. 2015). We had also subsequently used a similar tweet poem activity to introduce collective poetic inquiry to participants in a self-study research workshop (see Chisanga et al. 2014).

We began the tweet poem activity by asking each early-career academic to write down an anonymous 'tweet' in response to the prompt: 'What is your main concern about your teaching?' Tweets are usually used to communicate on the Twitter social network (https://twitter.com/) via cellular telephones or other handheld electronic devices. Through tweets people 'share brief updates for real-time and asynchronous communication with no more than 140 characters' (Gao, Luo and Zhang 2012, 783). We anticipated that using a tweet format would allow for 'just-in-time thoughts' (Gao et al. 2012, 789) of the participants to be expressed. We asked participants not to put their names on their tweets because we wanted them to feel free to express their views without fear of being judged by their colleagues (including us). The tweets (see, for example, Figure 1) formed the first set of field texts (data sources) for our narrative inquiry.

The written tweets were collected and the participants were divided into three groups. Each member of our research team joined a group as well. Our intention in joining the groups 
was not to lead them but rather to provide hands-on support for the poetry-making process that would follow. The tweets were divided into three random piles and every group was given a batch. We asked participants not to alert their fellow group members if they found their own tweet among those that their group received. In this way the tweets remained anonymous.

It was at this point that we introduced the idea of poetry to the participants. In our experience our colleagues - both novice and experienced academics - can feel uncomfortable with the unfamiliar idea of poetry-as-research (see Pithouse-Morgan et al. 2014). So we have learned to guide participants step by step through a process of creating research poetry to allow them to experience collective success in creating poems, without the inhibiting anticipation of individual failure (see Chisanga et al. 2014).

We asked each group to select from the tweets words and/or phrases that seemed particularly interesting or significant (see Figure 1), and to create a found poem using these words and phrases.

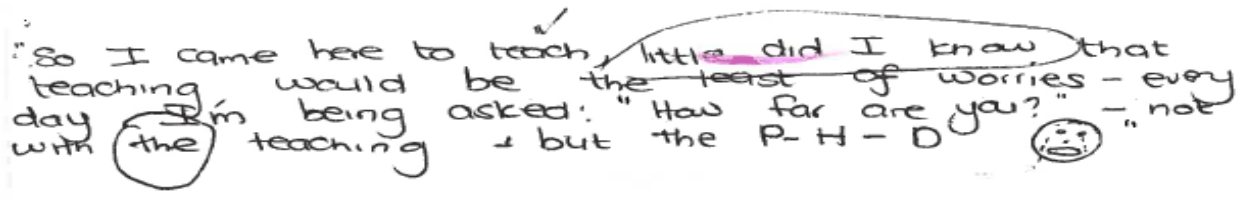

Figure 1: A tweet created by a participant, with words and phrases highlighted

As Butler-Kisber $(2005,96)$ explains, found poetry 'takes words distilled from field texts and shapes them into poetic form'. Each group had to create a found poem by agreeing on how to arrange the selected words and phrases from the tweets. After much discussion about which words and phrases to include and how to assemble them, each group composed a poem (see, for example, Figure 2). Our focus in this activity was not on the inherent artistic or literary merit of the poems themselves; rather, we anticipated that co-composing the found poems would offer participants a creative form of collective expression and also encourage them to look at the tweets through 'poetic eyes' to yield new and significant insights (Butler-Kisber 2002). In addition, we wanted to offer the early-career academics some concrete experience of how poetry can be used as a creative practice to generate or represent data in research (Richardson 2003). Hence, in the audio-recorded reflective conversation held with all the participants after the tweet poem activity, we were pleased to hear this comment: 'The creative manner in which we came to create the poems was very interesting to me. I gained a new skill and a research method that can be applied on any research project.' 
The three groups produced the following three poems: 'Little did I know ...'; 'Eating soup with a fork'; and 'That's my fate'. These poems formed our second set of field texts.

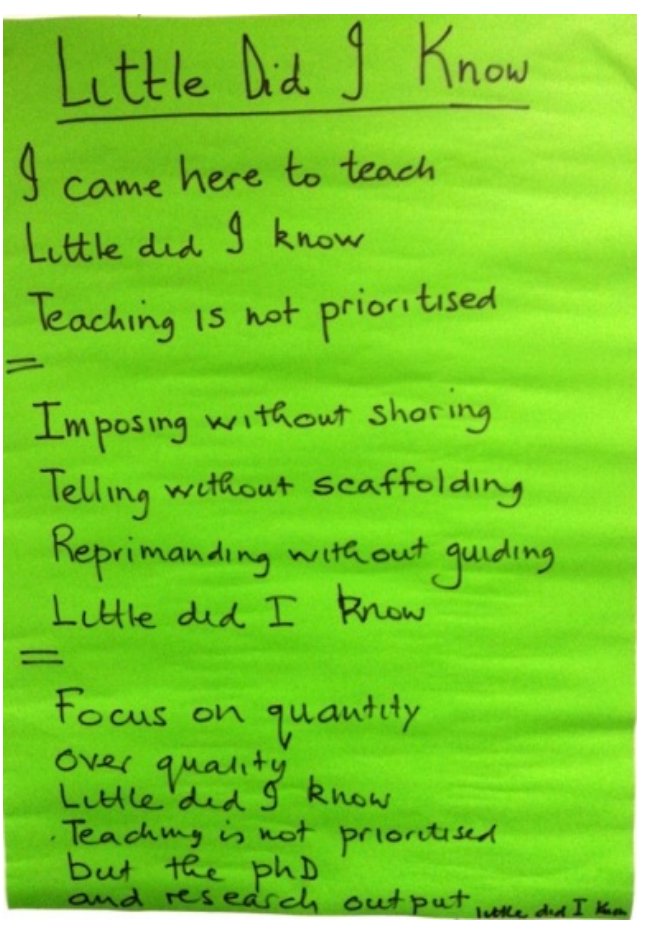

Figure 2: 'Little did I know': An example of a found poem created by one of the groups

\section{Little did I know}

I came here to teach

Little did I know

Teaching is not prioritised

Imposing without sharing

Telling without scaffolding

Reprimanding without guiding

Little did I know

Focus on quantity

Over quality

Little did I know

Teaching is not prioritised

But the $\mathrm{PhD}$

And research output

Little did I know

\section{Eating soup with a fork}

I feel that I'm blind

And I have to lead the blind.

The standard of education has dropped.

Students want to be spoon-fed.

The quality of graduates, 
Resource availability

Is of concern.

Being mentored by seasoned

And caring seniors is fabulous.

That's my fate

High workloads

Designing assignments and activities

No support

Lack of resources

I do my best

Pulled in different directions

To suit students

University jargon

Changes by management

I am tired

Is what we are teaching relevant?

Students are not serious

Students are dependent

Less opportunity to do research

Less opportunity to complete studies

That's my fate

Each group wrote the poem on a large poster which was pasted up on the front wall of the venue. We also asked the groups to perform the poems, in any manner that they felt was suitable. Our intention was to attend to the performative aspect of poetry-as-research by including the live enactment of poems and engagement with audience responses as a way of assisting the participants and us to deepen and extend our research learning and knowing (Wiebe 2008). All the poems were performed differently and the enactments were energetic and heartfelt. Each group's performance seemed to resonate with others and was received with laughter, applause and words of affirmation. With the consent of the participants we video recorded the performances. We clarified that this was to assist us in our research process and that to protect the anonymity of the early-career academics the video recording would not be made public.

Following the performances, we engaged in a 90-minute plenary discussion in response to the content and performances of the poems, as well as to the tweet poem activity itself. Our aim was to invite participants to further express and make meaning of their lived experiences as early-career academics as well as to reflect on the collective poetry-making process. Based on our prior experience we anticipated that the creative and participatory tweet poem process would have helped to establish an atmosphere of fellowship and mutual trust. Through the conversation we wanted to open a space for sharing with people with mutual experiences. 
This seemed to have been achieved, as we found that the early-career academics were keen to contribute to the discussion, as illustrated by this comment: 'I'm glad that there are people around us who know how I feel'. With the consent of the participants the discussion was audio recorded. The video recording of the performances and the audio recording of the plenary discussion became our third set of field texts.

Although the initial prompt for the tweets was 'What is your main concern about your teaching?', the discussion moved beyond that to include wider issues of becoming and being an academic. As is evident in the poems, the conversation touched on many of the concerns and challenges that are highlighted in international research literature on early-career academics' experiences. The comments made by the early-career academics correlated with what Eley et al. (2012, xvi) describe as 'a growing frustration over the low status that early career researchers have in institutions and how in many cases their needs have been overlooked both as individuals and at the institutional level'. As one participant explained: 'We've been with this thing for long, of not knowing where to go or how to go about it. You even doubt yourself. Am I in the right space? Is it too much for me? Do I need to go?' Another observed: 'I want to grow. But there were times when I would say, "But who cares? How am I going to do it?”' Another replied: 'When you ask someone, they will say, "Here, it's sink or swim".'

The discussion also correlated with global literature on the effects of corporate managerial practices on universities and academics. The early-career academics identified high workloads, a lack of resources and overcrowded classrooms as impediments to their performance in research and teaching. They also drew attention to 'one size fits all' prescribed individual performance targets, especially in terms of research publications, as a source of continuing stress and contributing to a lack of collegiality among academics.

Their comments illustrated Foote's $(2010,10)$ observation that in the prevailing academic climate early-career academics 'are encouraged to see academic life in terms of competition and struggle'. Overall the conversation exemplified not only that 'academics throughout the world deal with a substantial amount of ongoing occupational stress' (Barkhuizen and Rothmann 2008, 321), but also that new academics seem more susceptible to emotional fatigue, probably as a result of a combination of factors, including less welldeveloped coping strategies and higher teaching workloads (Watts and Robertson 2011).

International research also draws attention to how experiences of marginalisation and exclusion, related to 'racism, sexism, and other interlocking oppressions' (Bertrand Jones, Wilder and Osborne-Lampkin 2013, 327) can contribute to and exacerbate occupational stress 
in academia (Archer 2008; Bertrand Jones et al. 2013; Grummell, Devine and Lynch 2009; Lechuga 2012). This seems particularly significant in a context of university transformation in South Africa, which requires enhanced recruitment, academic development and retention of black and women academics (National Planning Commission 2012).

A concern raised by many participants and that seems particularly pressing in the South African higher education context is the national and institutional imperative for early-career academics to obtain $\mathrm{PhD}$ qualifications in as short a time as possible. This was mentioned as a significant stressor, especially when coupled with high teaching workloads and a requirement to produce research publications. We also noted that none of the early-career academics reported having been involved in any formal mentoring processes, although some did comment that they had benefitted from ad hoc mentoring from colleagues. The concluding lines to the second tweet poem, 'Being mentored by seasoned / And caring seniors is fabulous', seemed to reflect wishful thinking rather than the lived experiences of most earlycareer academics in the group.

\section{COMPOSING A RESEARCH POEM TO PORTRAY EARLY-CAREER ACADEMICS' STORIES OF EXPERIENCE}

Studying stories of lived experiences requires narrative researchers to transform an assortment of field texts into a cohesive research text. It is often in the construction of the research text that the meaning and significance of the field experiences (in our case, the tweet poem activity) become apparent (Clandinin and Connelly 2000). Following the tweet poem workshop our research team came together again to begin the process of creating a research text. We began by revisiting the field texts generated during the workshop. Together we listened to the audio-recorded conversation from the research workshop and looked at the tweets, the three tweet poems and the video-recorded poetry performances.

Creating a narrative research text frequently begins with a portrayal of stories of experience generated through the research activities (Clandinin and Connelly 1994). This descriptive portrayal provides a basis for later interpretation and conceptualisation. Following the example of Langer and Furman (2004) we decided to create a portrayal by composing a found poem from the three tweet poems. Our aim was that this new found poem would serve as a research poem, which as Langer and Furman (2004) explain, can be used to compress data generated by research participants and to offer 'a more powerful presentation of the data ... [through which] the emotional intensity and the poignancy of the [participants'] comments [can be] intensified for the researcher’ (paragraph 15). Langer and Furman further clarify that 
'the use of poetry as a presentation of data [can cause] a movement toward truly understanding the [participants] instead of just re-stating the conversation' (paragraph 15). We anticipated that co-composing a found poem from the three tweet poems would facilitate our collective listening to and learning from our early-career colleagues' stories of experience.

We projected photographs of the three tweet poem posters onto a screen and noted words and phrases that captured our interest and that we thought were most representative of the overall content of the diverse field texts. The process of selecting pieces of the tweet poems and deciding how to fit these pieces together in a new poem took us several hours. The collective poetry-making process required us to explicate our individual understandings of what we had heard from our early-career academic colleagues, and come to agreement on what to represent and how to do so through the found poem (Pithouse-Morgan et al. 2014). In the end we composed the following research poem 'Little did I know...':

\author{
Little did I know ... \\ I'm blind and I have to lead the blind \\ I am tired \\ Pulled in different directions \\ Changes by management \\ Imposing without sharing \\ Focus on quantity over quality \\ Being mentored? \\ I do my best \\ But the $\mathrm{PhD}$...
}

\title{
CREATING AN INTERPRETIVE POEM TO PORTRAY OUR UNDERSTANDING OF EARLY-CAREER ACADEMICS' STORIES OF EXPERIENCE
}

In narrative inquiry an initial descriptive portrayal of stories of experience provides material for a further, interpretive portrayal. In creating an interpretive portrayal narrative inquirers attempt to make sense of what they have learned in the field and to communicate these understandings to readers (Clandinin and Conolly 2000). This process of narrative interpretation can involve moving inward and outward, backward and forward, finding and exploring core narrative tensions (Conle 2000).

After composing our descriptive research poem, we met again to consider how to move to creating an interpretive portrayal. As we explain elsewhere (Pithouse-Morgan et al. 2015) a colleague who is in the field of Language and Media Education, introduced us to three prompts that she uses with her students to stimulate their responses to poetry. We had found these prompts very helpful in eliciting our responses to co-composed poetry in a collective poetic inquiry process (Pithouse-Morgan et al. 2015), and so decided to use the three prompts 
to guide us in discussing our research poem: What does the poem say? How does it say it? Is it worth saying? We audio recorded the ensuing conversation and as we spoke we also made notes in a Word document that was projected onto a screen.

In composing our interpretive portrayal, we again decided to follow the example of Langer and Furman (2004) by creating an interpretive poem. Langer and Furman explain the function of an interpretive poem as follows: 'Unlike the research poem, the purpose [is] not to create a poem based upon [the participants'] words, but to utilize poetic device to create an evocative and moving document which allows for the subjective responses of the researchers' (paragraph 16). Using the notes we had made in response to the three prompts, we created an interpretive poem to encapsulate and express our emerging understanding of our learning about and through listening to our early-career colleagues’ stories of experience.

For the interpretive poem we used the structure of a Tanka, which is a traditional Japanese poetic format (Furman and Dill 2015). We chose to use a version of the Tanka format that has five lines, with a 5/7/5/7/7 syllable count in the lines (poets.org n.d.). As Furman et al. (2006, 28) explain, 'the use of the Tanka, which is characterized by an extreme economy of words, forces the researcher to make decisions about what data should be included and what may be left out'. In using this format, we had to choose what we saw as the most significant of our responses to the three prompts to create a five-line poem. We were guided in this by what we had read about the configuration of the Tanka:

The Tanka employs a turn, known as a pivotal image, which marks the transition from the examination of an image to the examination of the personal response. This turn is located within the third line, connecting the kami-no-ku, or upper poem, with the shimo-no-ku, or lower poem (poets.org n.d., paragraph 3).

We created the following Tanka poem, 'Go forward together':

\author{
Go forward together \\ Overwhelmed, scattered \\ Vulnerable and exposed \\ Have to find your way \\ To go forward together \\ The self becomes the resource
}

The first two lines of the Tanka poem represent tensions that we saw in the participants' stories of negotiating their academic lives and work: 'Overwhelmed, scattered / Vulnerable and exposed'. These tensions do not seem to be unique to our institutional context or even to our national context. International research reveals a variety of significant and sometimes 
incapacitating tensions that many early-career academics encounter. Adcroft and Taylor (2013, 837) highlight a 'gap between preconceptions of academic careers and the reality of academic careers'. Hence new academics can enter into academia without fully understanding what it will entail. While the same might be said of entry into any number of careers, in academia this gap often seems to be compounded by a prevailing 'sink-or-swim philosophy' that 'stems from a view of the early career period as a rite of passage' and a belief that 'if an individual cannot do well without help, then - in the long run - that person probably does not have the talent and stamina needed to succeed in an academic career' (Foote 2010, 11).

Even if help is offered, the nature and quality of support offered to early-career academics seems to vary greatly, not only from institution to institution but across academic departments within the same institution (Foote 2010). Likewise, access to resources (including research grants, conference funding and teaching equipment and materials) can fluctuate across academic departments and can be negatively influenced by new academics' low status, their lack of knowledge of how to access available resources, or their lack of experience of competitive academic processes (McAlpine, Amundsen and Turner 2014). Compounding this is that early-career academics, who usually have not yet managed to build an extensive publications portfolio, are often given high teaching workloads and have not yet learned how to manage 'the relationship between teaching (which takes up agreat deal of time) and research (which is essential for career progression in universities ...)' (Adcroft and Taylor 2013, 837). These tensions, coupled with an absence of requisite coping strategies, can result in heightened feelings of insecurity, anxiety and unworthiness among early-career academics (Adcroft and Taylor 2013; Archer 2008; Foote 2010).

While much of the research into early-career academics' experiences highlights that they can benefit from '[sharing] the responsibility for their careers and [proactively engaging] in their own personal and career development' (Eley et al. 2012, xvii), it also draws attention to the hazards of insufficient institutional and collegial support (Price et al. 2014). Inadequate support can contribute to and intensify high levels of occupational stress for early-career academics, which can have severe consequences for their long-term psychological and physical health and in turn lower their work performance (Barkhuizen and Rothamann 2008; Mark and Smith 2012; Watts and Robertson 2011). Watts and Robertson (2011, 33) explain that ongoing occupational stress at universities can result in staff experiencing burnout, which is characterised by:

... the depletion of emotional reserves (emotional exhaustion), an increasingly cynical and negative approach towards others (depersonalisation) and a growing feeling of work-related 
dissatisfaction (personal accomplishment).

In addition, Foote $(2010,10)$ points out that without adequate and appropriate support, new academics tend to 'adopt ad hoc coping strategies, such as what Boice terms 'teaching defensively', that they may not question or change until much later in their careers'. As Allender and Allender $(2006,15)$ emphasise: 'Unless we are conscientiously aware of what is driving our choices of behavior in the classroom, we are all too likely to revert to the ways of the teachers who taught us - maybe for the good, but usually for the not so good'. Without time or collegial support to engage reflexively with their teaching practices, early-career academics are likely to teach by 'borrowing the techniques to which they were exposed as students' (Foote 2010, 15). These default teaching practices are unlikely to be responsive to the needs and interests of contemporary students or to contribute to the development of transformative institutional cultures.

This brings us to the third line of our Tanka poem: 'Have to find your way'. This line signifies a movement from the examination of tensions in our colleagues' stories of lived experience to the examination of our personal response. Somehow early-career academics must find ways to manage the tensions they encounter. As discussed above, it can be personally and professionally damaging for early-career academics not to be supported in cultivating proactive coping strategies. A 'sink or swim' philosophy is not helpful for the professional development of early-career academics or for the growth and achievements of a university community as a whole.

The closing lines of the Tanka poem communicate our subjective response to the tensions portrayed in the opening lines. The lines 'To go forward together / The self becomes the resource' reveal as much about us as researchers as they do about our research topic. Our experiences of becoming and being academics are not far removed from those of our research participants. Two of us (Inbanathan and Kathleen) were until quite recently early-career academics ourselves. Lungile is currently an early-career academic and, as a doctoral student, Teboho is on his way to becoming an early-career academic. Although further along on her academic path, Daisy has not forgotten her early-career experiences. In our discussion of the research poem we talked about what made a difference to us in negotiating the tensions of early-career academia, and what still makes a difference to us in navigating the continuing tensions we face.

As Archer $(2008,401)$ highlights, "the "new times” of contemporary academia, with the increased pressures for performance and production, are, arguably, as likely to engender feelings of anxiety and inauthenticity among “older” and/or more senior academics'. As 
'older' academics, Daisy, Inbanathan and Kathleen continue to experience occupational stress, but have developed 'shock absorbers' that alleviate this stress. These shock absorbers comprise a certain level of academic self-belief and self-confidence that has grown over time, as well as supportive relationships with like-minded colleagues that have also grown over time. We see these two elements - the self-resourcefulness and the togetherness - as interconnected and mutually sustaining (Pithouse-Morgan et al. 2015).

From their perspectives as an early-career academic and doctoral student, Lungile and Teboho find that being self-resourceful is still work in progress. On the verge of sinking into the mire of work-related stress, the lifeline comes in the form of more experienced academics who provide on-call support. There is a need for new academics to develop a sharp eye for identifying willing academic mentors and to ask for the specific type of mentoring that is required at various times. Self-belief also becomes part of the work in progress when earlycareer academics receive affirmation from those that mentor them.

Our collective response to the tensions of early-career academia - 'To go forward together / The self becomes the resource' - is mirrored in recommendations made in literature on development and support for early-career academics. The importance of collegial relationships is repeatedly emphasised. For example, Adcroft and Taylor $(2013,837)$ highlight that 'much career support is grounded in the relationships between experienced and less experienced academics’. Dwyer, Lewis, McDonald and Burns (2012) also draw attention to how peer support groups can boost early-career academics’ professional performance and increase their sense of professional accomplishment. Foote (2010) points out that building collegial relationships across academic departments and across universities can extend new academics’ professional learning and increase their self-assurance by helping them to feel part of a wider academic community. Furthermore, Eley et al. (2012) emphasise how involvement in research teams within and/or across institutions can enhance the research productivity of early-career academics.

However, the prevailing corporatisation discourse, which positions individual academics, academic departments and institutions as competitors rather than collaborators, can impede the growth of mutually beneficial collegial relationships (Archer 2008). Also, as Cox (2001) indicates, a lack of institutional recognition or rewards for spending time and money on building collegial relationships can undermine efforts to support the development of early-career academics. If, as Adcroft and Taylor $(2013,838)$ found, the 'success or otherwise of the professional and personal support offered to new academics [is] primarily determined by the human relationships involved', then it is vital that universities and national 
higher education bodies pay specific attention to facilitating the growth of collegial relationships as an intrinsic part of developing transformative institutional and interinstitutional cultures. Prerequisites for this include time and recognition for formal and informal mentoring of early-career academics by senior colleagues; time and backing for early-career academics to initiate and sustain peer support groups; and time and funding for new academics to build more extensive networks by attending inter-institutional and international professional meetings (Adcroft and Taylor 2013; Cox 2011; Foote 2010).

Conductive conditions for the growth of collegial relationships, combined with 'a suite of professional development opportunities which staff can access as and when they feel it appropriate for their individual career development' (Adcroft and Taylor 2013, 837), are critical to development of the self-resourcefulness and self-belief that can enable early-career academics to cultivate positive coping strategies and plot their own course in becoming and being academics (Archer 2008; Cox 2011; Foote 2010; Mark and Smith 2012).

\section{LEARNING FROM STORIES OF BECOMING ACADEMICS WITHIN A TRANSFORMING UNIVERSITY TERRAIN}

Taking a collective poetic narrative inquiry approach provided each one of us space for being resourceful and thinking resourcefully with and about early-career academics. Their stories and ours are entangled in our learning about what it means to be (or not to be) an academic in a continually shifting higher education landscape. Imaginative engagement through poetry provided opportunities to turn the venting of tensions and concerns into a search for new understandings of how we might find our way together in academia. Our resourcefulness involved our collective commitment to embrace poetic narrative inquiry as an evocative and reflexive way of learning and knowing. This commitment to awakening new possibilities for research was underpinned by values of mutual trust and respect.

Through our learning from our early-career colleagues’ stories of becoming and being academics we acknowledge our interdependence as academics. As newer and older academics working together, we become 'shock absorbers' for and to each other. We learn about and through each other what we can do and should do to navigate the uncertain terrain of academia. Collegial professional communities and conducive conditions can open up possibilities where supportive relationships and self-resourcefulness can be cultivated simultaneously. Cultivating an academic climate where interdependence is seen as resourceful is necessary and helpful for our growth as new and older academics. Through collective participation novice and experienced academics can become valuable sources of learning and 
support for each other.

\section{ACKNOWLEDGEMENTS}

We gratefully acknowledge funding from a University Teaching and Learning Office (UTLO)

Institutional Research Grant for our project: New Scholarship in Teaching and Learning in

Higher Education. We are also appreciative of the contributions of our colleague, Thabo

Msibi, as a collaborator on this project.

\section{REFERENCES}

Adcroft, A. and D. Taylor. 2013. Support for new career academics: An integrated model for research intensive university business and management schools. Studies in Higher Education 38(6): 827840.

Allender, J. and D. Allender. 2006. How did our early education determine who we are as teachers? In Collaboration and community: Pushing boundaries through self-study. Proceedings of the Sixth International Conference on Self-Study of Teacher Education Practices, Herstmonceux Castle, East Sussex, England, July 30-August 3, ed. L. M. Fitzgerald, M. L. Heston and D. L. Tidwell, 14-17. Cedar Falls, IA: University of Northern Iowa Press.

American Heritage ${ }^{\circledR}$ Dictionary of the English Language, 5th edition. 2011. 'Prosaic'. http://www.thefreedictionary.com/prosaic (accessed 17 March 2015).

Archer, L. 2008. Younger academics' constructions of 'authenticity', 'success' and professional identity. Studies in Higher Education 33(4): 385-403.

Badat, S. 2010. The challenges of transformation in higher education and training institutions in South Africa. Midrand: Development Bank of Southern Africa.

Barkhuizen, N. and S. Rothmann. 2008. Occupational stress of academic staff in South African higher education institutions. South African Journal of Psychology 38(2): 321-336.

Bertrand Jones, T., J. Wilder and L. T. Osborne-Lampkin. 2013. Employing a black feminist approach to doctoral advising: Preparing black women for the professoriate. Journal of Negro Education 82: 326-338.

Butler-Kisber, L. 2002. Artful portrayals in qualitative inquiry: The road to found poetry and beyond. Alberta Journal of Educational Research 48(3): 229-239.

Butler-Kisber, L. 2005. Inquiry through poetry: The genesis of self-study. In Just who do we think we are? Methodologies for autobiography and self-study in teaching, ed. C. Mitchell, S. Weber and K. O’Reilly-Scanlon, 95-110. London: RoutledgeFalmer.

Caulley, D. N. 2008. Making qualitative research reports less boring. Qualitative Inquiry 14(3): 424449.

Chisanga, T., W. Rawlinson, S. Madi and N. Sotshangane. 2014. Enacting reflexivity through poetic inquiry. Educational Research for Social Change 3(2): 21-36.

Clandinin, J. 2013. Engaging in narrative inquiry. Walnut Creek, CA: Left Coast Press.

Clandinin, D. J. and F. M. Connelly. 1994. Personal experience methods. In Handbook of qualitative research, ed. N. K. Denzin and Y. S. Lincoln, 413-427. Thousand Oaks, CA: Sage Publications.

Clandinin, D. J. and F. M. Connelly. 2000. Narrative inquiry: Experience and story in qualitative research. San Francisco: Jossey-Bass Publishers.

Clare, J. and R. Sivil. 2014. Autonomy lost. The bureaucratisation of South Africa HE. South African Journal of Higher Education 28(1): 60-71.

Conle, C. 1999. Why narrative? Which narrative? Struggling with time and place in life and research. 
Curriculum Inquiry 29(1): 7-32.

Conle, C. 2000. Thesis as narrative or 'What is the inquiry in narrative inquiry?' Curriculum Inquiry 30(2): 189-214.

Connelly, F. M. and D. J. Clandinin. 1994. Narrative inquiry. In The international encyclopaedia of education, ed. T. Husen and T. Postlethwaite, 2nd ed., 4046-4051. Oxford: Elsevier Science.

Cox, M. D. 2011. The impact of communities of practice in support of early-career academics. International Journal for Academic Development 18(1): 18-30.

Debowski, S. 2012. The new academic: A strategic handbook. Buckingham: Open University Press.

Dwyer, A., B. Lewis, F. McDonald and M. Burns. 2012. It's always a pleasure: Exploring productivity and pleasure in a writing group for early career academics. Studies in Continuing Education 34(2): 129-144.

Eisner, E. W. 1997. The promise and perils of alternative forms of data representation. Educational Researcher 26(6): 4-10.

Eley, A., J. Wellington, S. Pitts and C. Biggs. 2012. Becoming a successful early career researcher. London: Routledge.

Fitzmaurice, M. 2013. Constructing professional identity as a new academic: A moral endeavour. Studies in Higher Education 38(4): 613-622.

Foote, K. E. 2010. Creating a community of support for graduate students and early career academics. Journal of Geography in Higher Education 34(1): 7-19.

Furman, R. and L. Dill. 2015. Extreme data reduction: The case for the research Tanka. Journal of Poetry Therapy 28(1): 43-52.

Furman, R., C. A. Lietz and C. L. Langer. 2006. The research poem in international social work: Innovations in qualitative methodology. International Journal of Qualitative Methods 5(3): 2434.

Gao, F., T. Luo and K. Zhang. 2012. Tweeting for learning: A critical analysis of research on microblogging in education published in 2008-2011. British Journal of Educational Technology 43(5): 783-801.

Grummell, B., D. Devine and K. Lynch. 2009. The care-less manager: Gender, care and new managerialism in higher education. Gender and Education 21(2): 191-208.

Habib, A. 2010. Reflections of a bureaucrat. Paper delivered at the 'Aims of Higher Education' roundtable held at Rhodes University, Grahamstown, October 27-29.

Langer, C. and R. Furman. 2004. Exploring identity and assimilation: Research and interpretive poems. Forum Qualitative Sozialforschung / Forum: Qualitative Social Research 5(2), Article 5. http://www.qualitative-research.net/index.php/fqs/article/view/609 (accessed 30 January 2013).

Lechuga, V. M. 2012. Emotional management and motivation: A case study of underrepresented faculty. New Directions for Institutional Research 155: 85-98.

Leggo, C. 2008. Astonishing silence: Knowing in poetry. In Handbook of the arts in qualitative research, ed. J. G. Knowles and A. L. Cole, 165-174. Thousand Oaks, CA: Sage Publications.

Mark, G. and A. P. Smith. 2012. Effects of occupational stress, job characteristics, coping, and attributional style on the mental health and job satisfaction of university employees. Anxiety, Stress, \& Coping 25(1): 63-78.

Masinga, L. 2012. Journeys to self-knowledge: Methodological reflections on using memory-work in a participatory study of teachers as sexuality educators. Journal of Education 54: 121-137. http://joe.ukzn.ac.za/Libraries/No_54_2012/Masinga.sflb.ashx (accessed 15 January 2013)

McAlpine, L., C. Amundsen and G. Turner. 2014. Identity-trajectory: Reframing early career academic experience. British Educational Research Journal 40(6): 952-969.

Naicker, I., P. Morojele, K. Pithouse-Morgan, D. Pillay and V. Chikoko. 2014. Moving towards curriculum intellectualising in the context of divergent notions of African scholarship. African 
Studies: 1-13. http://dx.doi.org/10.1080/00020184.2014.922273 (accessed 15 January 2015)

National Planning Commission. 2012. National Development Plan 2030: Our future-make it work. Pretoria: Government Press.

Pithouse-Morgan, K., C. Mitchell and D. Pillay. 2014. Editorial: Enacting reflexivity in educational research. Educational Research for Social Change 3(2): 1-4.

Pithouse-Morgan, K., I. Naicker, V. Chikoko, D. Pillay, P. Morojele and T. Hlao. 2014. Entering an ambiguous space: Evoking polyvocality in educational research through collective poetic inquiry. Perspectives in Education 32(4): 149-170.

Pithouse-Morgan, K., N. Muthukrishna, D. Pillay, L. Van Laren, T. Chisanga, T. Meyiwa, R. Moletsane, I. Naicker, L. Singh and J. Stuart. 2015. Learning about co-flexivity in a transdisciplinary self-study research supervision community. In Polyvocal professional learning through self-study research, ed. K. Pithouse-Morgan and A. P. Samaras, 145-171. Rotterdam: Sense Publishers.

poets.org. n.d. Poetic form: Tanka. http://www.poets.org/poetsorg/text/poetic-form-tanka (accessed 15 February 2014).

Price, E., B. Coffey and A. Nethery. 2014. An early career academic network: What worked and what didn't. Journal of Further and Higher Education: 1-19.

Online Etymology Dictionary. 2001-2014. 'Prose.' http://www.etymonline.com/index.php?allowed _in_frame $=0 \&$ search=prose\&searchmode $=$ none (accessed 17 March 2015).

Online Etymology Dictionary. 2001-2014. 'Reflexive'. http://www.etymonline.com/index.php? allowed_in_frame=0\&search=reflexive\&searchmode=none (accessed 17 March 2015).

Reid, I. C. 2009. The contradictory managerialism of university quality assurance. Journal of Education Policy 24(5): 575-593.

Richardson, L. 2003. Writing: A method of inquiry. In Collecting and interpreting qualitative materials, ed. N. K. Denzin and Y. S. Lincoln, 2nd ed., 499-541. Thousand Oaks, CA: Sage Publications.

Sand-Jensen, K. 2007. How to write consistently boring scientific literature. Oikos 116: 723-727.

Sternberg, R. J. 2014. Murky environments in academe. The Chronicle Review, June 16.

Teferra, D. 2014. 'Organised anarchy' - the enduring paradigm of university management. University World News: 329. http://www.universityworldnews.com/article.php?story=20140716075612402 (accessed 12 August 2014).

Van Laren, L., K. Pithouse-Morgan, T. Chisanga, L. Harrison, T. Meyiwa, N. Muthukrishna, I. Naicker and L. Singh. 2014. 'Walking our talk': Exploring supervision of postgraduate selfstudy research through metaphor drawing. South African Journal of Higher Education 28(2): 639-659.

Van Manen, M. 1990. Researching lived experience: Human science for an action sensitive pedagogy. Albany, NY: State University of New York Press.

Walford, G. 1991. Reflexive accounts of doing educational research. In Doing educational research, ed. G. Walford, 1-18. London; New York: Routledge.

Watts, J. and N. Robertson. 2011. Burnout in university teaching staff: A systematic literature review. Educational Research 53(1): 33-50.

Wiebe, N. G. 2008. Mennocostal musings: Poetic inquiry and performance in narrative research. Forum Qualitative Sozialforschung / Forum: Qualitative Social Research 9(2): Art. 42. http://nbn-resolving.de/urn:nbn:de:0114-fqs0802423 (accessed 30 January 2013). 